\title{
Management of trade credit by small and medium-sized enterprises
}

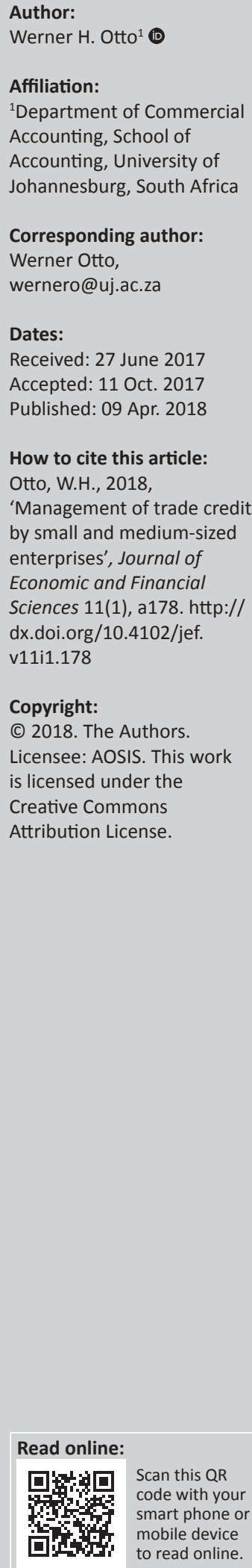

\begin{abstract}
This study identifies the trade credit management situation within the small and mediumsized enterprise (SME) environment. The purpose of this study is to determine the trade credit management practices of SMEs, focussing on debtors alone, in order to establish whether South African SMEs mismanage trade credit. Focussing on SMEs, this study created a unique opportunity to determine the trade credit management practices of SMEs specifically. This article provides vital evidence containing SMEs' trade credit management practices and insight to entrepreneurs (SME owners) and government regarding possible reasons why SMEs find it difficult to manage trade credit effectively. Data were analysed using statistical techniques such as descriptive statistics, frequencies, cross-tabulations and mean scores. The intention is that SMEs and small firms can use the results of this study in assessing the appropriateness and effectiveness of their own practices and, in doing so, contribute towards the sustainability and viability of SMEs in order to empower SMEs to operate successfully in addressing the South African development challenges.
\end{abstract}

\section{Introduction}

The inability of financial managers to properly plan and control current assets and current liabilities is an important reason behind the high failure rate of small and medium-sized enterprises (SMEs). SMEs rely more heavily on trade credit, owner equity (internal capital) and short-term bank loans in order to finance their needed investment in current assets such as debtors, inventory and cash. The failure rate of SMEs in South Africa is very high (Mass \& Herrington 2006), even when compared to that of large firms. Studies in both the United Kingdom and the United States have shown that poor short-term financial management, particularly poor trade credit and working capital management, is a primary cause of failure among SMEs (Padachi 2006). The recurring and widespread practice of late debtor collections can eventually deteriorate the financial position of the provider of trade credit (Zainudin \& Regupathi 2011). Zainudin and Regupathi (2011) further add: 'Prudent trade credit management is a vital component of success and survival, particularly to the SMEs'.

Trade credit is an important source of financing for the majority of SMEs (Peel, Wilson \& Horworth 2000). Trade credit derives from the normal day-to-day business transactions between organisations and can be classified as a spontaneous source of finance for such organisations (Fatoki 2010). Trade credit arises when a buyer of goods or services makes a delayed payment to a supplier of goods or services (Fatoki \& Smit 2010). The buyer of goods or services delays the payment to the supplier while receiving goods or services immediately. Trade credit represents an investment for the seller of goods or services in current assets (debtors), while for the buyer of goods or services it is an important form of funding that is classed under current liabilities (creditors) (García-Teruel \& Martínez-Solano 2010). External debt financing, such as trade credit, is one of the most important sources of funding for new SMEs (Kauffman Foundation 2007). Padachi (2006) adds that working capital management and specifically the management of trade credit are of particular importance to the small firm.

Commercial bank lending, which supplies SMEs with slightly more credit compared to trade credit, has received much more attention than trade credit as a form of finance to SMEs (Berger \& Udell 2006). Trade credit is of particular importance to SMEs because of the fact that small firms find it difficult to obtain funding through credit institutions (García-Teruel \& Martínez-Solano 2010). SMEs rely mostly on short-term debt finance (García-Teruel \& Martínez-Solano 2007; Peel et al. 2000), use less external finance in the form of bank loans (Beck, Demirguc-Kunt \& Peria 2008) and their access to long-term capital markets is significantly limited (Petersen \& Rajan 1997). Trade credit is usually extended for an intermediate period of 30-60 days, at which point payment 
is due. Penalties in the form of financing charges are applied on the outstanding balance owed by a customer if payment is not received on the date as agreed upon between the provider of credit and the receiver of credit. Therefore, trade credit becomes an alternative method of financing business expenses (Fatoki 2010). Fatoki and Smit (2010) identify three main reasons why trade credit, and the use thereof by SMEs, is important. Firstly, new SMEs should consider using trade credit as a form of finance, especially in early years of business when the risk of default and financial loss for a SME is high. Secondly, in financing the working capital needs of SMEs, trade credit is often the best or only available source of external capital as a result of limited access to bank loans. Thirdly, trade credit serves as a perfect substitute for bank loans in the case of SMEs that are credit-rationed by financial institutions.

Trade credit can be identified as a 'two-way transaction' (Peel et al. 2000). Accordingly, many firms not only use trade credit as customers but also provide it as suppliers. It is critical for SMEs to manage the net trade credit position effectively. With trade credit being a 'two-way transaction' in nature, it is essential to differentiate between as well as understand the importance of both granting trade credit and receiving trade credit (Wilson \& Summers 2002). Trade credit can be divided into two components, namely debtors who represent the assets or investment side of trade credit and/or creditors who represent the liability or financing side of trade credit. Whited (1992) and Fazzari and Petersen (1993) explained that most of an SMEs assets, mainly in the form of current assets, are financed through current liabilities because of financial constraints faced by SMEs, thus emphasising the importance of effective trade credit management.

Various factors contribute towards the decision of granting trade credit and the importance thereof for SMEs, in particular. The decision to grant trade credit, in an attempt to increase sales and, ultimately, also profit, will provide a platform for SMEs to receive trade credit. Trade credit can be received from a lender or supplier of trade credit, enabling SMEs to finance their own operations (Fatoki \& Smit 2010). Furthermore, trade credit is a more cost-effective form of finance, especially when compared to the cost of commercial debt and long-term lending. For the majority of SMEs, trade credit provides a means of accessing certain markets when SMEs provide trade credit to buyers of goods or services. Lastly, trade credit can be used as a mechanism to stop price discrimination and price competition and ultimately increase sales, thus again increasing profit (García-Teruel \& Martínez-Solano 2010).

As stated earlier, SMEs can also utilise or receive trade credit as customers whereby SMEs finance purchases made from suppliers of products or services. Therefore, in identifying the importance of receiving trade credit, it should be noted that trade credit reduces the transaction cost associated with paying bills for the buyer of goods or services because a receiver of trade credit can accumulate payment obligations and pay on a quarterly or monthly basis (Petersen \&
Rajan 1997). In addition, when receiving trade credit, SMEs can improve their cash-flow forecasts and simplify their ever important cash management system (Fatoki \& Smit 2010). Furthermore, credit-rationed SMEs can receive trade credit and use it as a substitute to bank credit. Lastly, trade credit reduces the financial risk and risk of default for SMEs that are making use of bank loans in the early years of operation.

Fewer firms will fail and economic growth will ultimately increase substantially when all aspects of trade credit are managed more effectively in organisations (Peel \& Wilson 1996). Given the advantages attached to effective trade credit management and it being a primary cause of failure, specifically for SMEs, the focus of this study is to determine the trade credit management practices of SMEs and identify if SMEs find it difficult to manage trade credit effectively. This article aims to indicate the trade credit management practices of SMEs, especially related to their management of debtors, and how these practices constrain SMEs sustainability.

The next section reviews the literature pertaining to trade credit management in SMEs.

\section{Literature review}

In a developing country such as South Africa, the three main development challenges are unemployment, income inequality and poverty (World Bank 2008). The ability of the SME to survive and develop into a sustainable enterprise holds the key to solving these development challenges. The Global Entrepreneurship Monitor (GEM) observes that the GEM survey, in which South Africa has participated since 2001, provides useful data on both the extent and the nature of entrepreneurial activity in South Africa (Herrington, Kew \& Kew 2009). It was found that $75 \%$ of all new SMEs in South Africa fail within the first 2 years of business and that the creation rate of new SMEs in South Africa is one of the lowest in the world compared to other developing countries (Von Broembsen, Wood \& Herrington 2005). In addition, the probability of new SMEs growing towards an established business and surviving beyond 42 months is less likely in South Africa than in any other GEM countries sampled in 2005 (Von Broembsen et al. 2005).

In 2008, South Africa ranked 23rd out of 43 countries, with a Total Early-Stage Entrepreneurial Activity (TEA) of 7.8\%, which was below the average TEA rate $(10.6 \%)$ of all the countries surveyed by GEM (Herrington et al. 2009) and significantly lower than the average for all developed countries $(11.4 \%)$ as well as the average for all middle- to low-income countries. The purpose of the TEA rate is to serve as the primary measure of new small firm creation used by GEM. Therefore, South Africa's low new SME creation rate paints a bleak picture of the current potential for the country's SME sector to positively contribute towards addressing the challenges of job creation, economic growth and more equal income distribution. Furthermore, only $2 \%$ of new SMEs in South Africa are able to access external debt such as bank 
loans (long-term debt) to use as capital in order to finance operations and long-term projects as pointed out by FinMark Trust (2006). Evidence obtained in a study conducted by Balkenhol and Evans-Klock (2002) shows that the use of trade credit by new SMEs in South Africa is as low as $0.2 \%$. This can be attributed to trade credit being mismanaged by SMEs along with the unavailability of trade credit in the SME sector, causing SMEs to neglect trade credit and ultimately forcing them to find other forms of short-term finance.

The vast majority of SMEs neglect the practice of managing working capital. The SMEs thus often run out of cash and become insolvent (Sunday 2011). A problem for smaller firms is the late payment of commercial debt that leads to financial distress and ultimately constrains growth among smaller firms (Wilson \& Summers 2002). The lack of planning and insufficient management for increasing working capital needs can lead to serious cash-flow problems. A large number of new and existing SMEs, therefore, fail to grow into viable and sustainable businesses as a result of poor working capital management (Fatoki 2010). Fatoki (2010) further emphasises that many SMEs find it difficult to manage their working capital effectively. Inadequate financial management and poor planning for cash requirements, in particular, are the main reasons why SMEs struggle with cash-flow problems. Furthermore, not only is the management of trade credit and/or working capital important for the survival of new and existing SMEs but also the availability of working capital (therefore, the willingness to grant trade credit) is also one of the critical success factors for new SMEs (García-Teruel \& Martínez-Solano 2007). Many SMEs find it difficult to manage their working capital effectively.

As a result of poor management of trade credit, SMEs can be considered a credit risk to banks, suppliers and/or other financial institutions. The credit risk of new SMEs is the most important reason why banks and suppliers often reject credit applications (Tagoe, Nyarko \& Smurfit 2005). As providers of credit, SMEs often neglect their credit policy, while credit management activities are also badly managed. In addition, SMEs' poor management of credit ultimately contributes to poor management of trade credit within the small firm (Poutziouris, Michaelas \& Soufani 2005). As receivers of trade credit, small firms exhibit volatile cash flow, but rely on trade credit as an important source of finance (Peel et al. 2000). As a result of the volatility in cash flow for small firms and their dependence on trade credit as a form of finance, the importance of correctly managing trade credit should be emphasised.

Small and medium-sized enterprises experience various negative consequences resulting from poor management of trade credit. The following consequences were identified when studying the trade credit terms offered for the small firm (Wilson \& Summers 2002): the existence of a strained and/or damaged relationship between debtor and creditor of the firm; the inability of the small firm to capture new business for its product offering; and, ultimately, a bad 'reputation' and poor financial health for the small firm. In addition to the above, another negative consequence resulting from poor management of trade credit is that SMEs find themselves in an inadequate cash situation, leading to their inability to repay their own obligations as they become due and their ultimate insolvency. The above consequences have a negative 'spill-over' effect in industries where SMEs are closely related to each other and, ultimately, influence the individual SME, the market and the overall economy negatively. The vast majority of SMEs, and particularly those at intermediate points in the value chain, use trade credit for two primary purposes: to receive credit as a customer and to provide credit as a supplier (Wilson \& Summers 2002). SMEs operating in the same industry are closely related because the vast majority of SMEs extend and receive trade credit from each other on a continuous basis. This situation indicates the dependence between SMEs in the same industry, thus emphasising the possibility of a 'spillover' effect.

When selling products or services on credit, debtors are a form of investment in any enterprise, and therefore, large sums of funds are tied up in trade debtors. This emphasises the importance of effective trade credit management to ensure a positive contribution towards an increase in turnover and profits, while minimising large sums of funds tied up in trade debtors and effectively placing less strain on cash-flow demands. Although debtors are a form of investment, funds should not be tied up for long periods of time and should be liquid in order to provide the needed cash to ensure the repayment of obligations (Barad 2010). SMEs extend credit to customers and make purchases on credit; thus, the risk of customers falling behind on their payments ever exists. Ultimately, SMEs find themselves with uncollected debt, effectively placing immense strain on cashflow demands because of the unavailability of cash within the SME. An up-to-date credit policy helps an SME to proactively manage its outstanding invoices (Peavler 2012). The payment arrangement between firms is, in effect, based on credit terms, unless the transaction between the firms involved occurs immediately (Ng, Smith \& Smith 1999).

Trade credit can be divided into two basic forms, namely the simpler form, net terms, and the more complex form of trade credit, two-part terms. The simpler form of trade credit, net terms, specifies that full payment is due within a certain period after delivery of a product or service or after monthly statements. For example, 'net 30 ' means that full payment is due 30 days after the date of invoice; the buyer is in default if the account is not paid before that date. Invoicing of the product or service normally occurs around the date of delivery of the product or service. The more complex form of trade credit, two-part terms, consists of three basic elements, namely the discount percentage, the discount period and the final payment time. The most common two-part term used by SMEs is ' $2 / 10$ net 30' (Fatoki 2010). This represents a $2 \%$ discount for payment within the 10-day discount period; the net period ends on day 30 . The ' $2 / 10$ net 30 ' payment term defines an implicit interest rate of $43.53 \%$ to the buyer 
agreeing to this term of payment (Fatoki 2010). If the buyer is not able to pay within the 10 -day discount period, the $43.53 \%$ becomes the opportunity cost to the buyer in exchange for 20 additional days of financing. The buyer will be in default, should they not be able to repay the account by the end of the net period.

In developing and managing the credit policy, it is critical for an SME to address all components as set out within the credit policy or formal agreement. The key components of a credit policy are credit period, cash discount, credit analysis, collection policy, evaluating credit policy, management of debtors and age analysis of debtors (Marx et al. 2009). Furthermore, there are several incentives for a firm to extend trade credit to its customers (Main \& Smith 1992). These incentives include cost advantages and market power through effective price discrimination for the firm. Additional advantages of extending trade credit are that a firm can increase its customer loyalty and goodwill among customers and that a firm's customers are likely to spend even more money on products and services offered. The disadvantage of extending trade credit is the possibility of customers not paying their outstanding account. There is the possibility of bad debts if any percentage of SMEs sales is on credit. This emphasises the importance of a more rigid credit policy, which will effectively help avoid greater defaults in payments by financially weak or distraught customers, resulting in a bigger volume of debtors for the SME (Peavler 2012).

Several factors have been identified that will influence an SME's decision as to whether or not to extend trade credit to customers or other SMEs. These factors include the effect on sales revenue, the effect on cost of goods sold, the probability of bad debts, the offer of a cash discount and the implications of taking on or granting debt. Regardless, the effective management of trade credit depends, to a large extent, on the existence of a sound and structured credit policy that exerts rigid credit terms as set out within the policy (Peavler 2012).

Identifying the problems resulting from ineffective trade credit management by SMEs could, therefore, both decrease the failure rate and increase the creation rate of new and existing SMEs. Therefore, the focus of this article is to identify the trade credit management practices of SMEs contributing towards ineffective trade credit management, which ultimately impairs the sustainability of the SME.

The next section examines the research methodology applied.

\section{Research methodology}

Research related to the management of trade credit in SMEs can be classified as explanatory quantitative research. The issue regarding trade credit management in SMEs has been examined in developed countries, but only to a certain extent, while the South African situation and context have not been examined in great detail. This study follows the survey research approach as the data-collection method.
The questionnaire was peer-reviewed by academics related to the field of study as a measure taken to contribute to the research instrument validity, before distribution of the research instrument. Thereafter, the research instrument was adjusted to incorporate the reviewer's comments. Questionnaires were sent electronically via e-mail (e-mailed questionnaire) to gather the data obtained by means of the survey for the completion of this study. QuestionPro was used as the web-based software program for the creation and distribution of the online questionnaire. The questionnaire consisted mainly of close-ended questions (five-point Likert scale-type questions). With regard to sampling design, in terms of population, the researcher used probability sampling (simple random sampling). The population of SMEs was obtained from the Centre for Development Studies (CDS) that published a list of SMEs in the Mangaung district in 2012. This list includes SMEs within the agricultural, construction, financial, food, health, manufacturing, retail, solar, transport and distribution, as well as wholesale industries. The sectors that account for the most trade credits are wholesale, along with the retail and manufacturing sector (Selima 2007). These were thus included in the study sample. This list of SMEs, from the CDS, was generated from the yellow and white telephone book for the city of Mangaung in the Free State province. All SME names were cross-checked to eliminate double counting. There was a total population of 352 SMEs in this study. Of the 352 questionnaires administered to SMEs, a total of 152 questionnaires were returned, representing a response rate of $43.2 \%$.

The data-collection method used in this study consisted of structured questionnaires distributed via e-mail to respondents. A self-designed questionnaire based on literature aimed to verify the trade credit management practices of SMEs and the challenges they face and, in doing so, to determine their attitudes and behaviours concerning trade credit management. Once the data were collected, the SPSS (version 21.0 for Windows) software program was used in the statistical analysis of the data. The statistical techniques of descriptive statistics, frequencies, cross-tabulations and mean scores were used to analyse the data.

The next section concerns the analysis of the results of the empirical study.

\section{Empirical results}

The empirical results introduce an indication of SMEs trade credit management practices.

\section{Small and medium-sized enterprises' number of active debtor accounts}

Table 1 illustrates the number of active debtor accounts that SMEs possess as an indication of their trade credit extension capacity.

The findings in Table 1 indicate that approximately $26 \%$ of the respondents have between 81 and 100 debtor accounts; $25 \%$ have between 21 and 40 debtor accounts; and approximately 20\% have between 1 and 20 debtor accounts. 
TABLE 1: Number of debtor accounts.

\begin{tabular}{lcc}
\hline Number of debtor accounts & Frequency & Percentage \\
\hline 0 & 8 & 5.3 \\
$1-20$ & 31 & 20.4 \\
$21-40$ & 38 & 25.0 \\
$41-60$ & 22 & 14.5 \\
$61-80$ & 5 & 3.3 \\
$81-100$ & 40 & 26.3 \\
101 and above & 8 & 5.3 \\
\hline Total & $\mathbf{1 5 2}$ & $\mathbf{1 0 0 . 0}$
\end{tabular}

TABLE 2: Small and medium-sized enterprises' perception of the effectiveness of current credit policy.

The extent to which the respondent perceives its Frequency Percentage Mean SMEs credit policy to be effective

\begin{tabular}{lccc}
\hline Not effective at all & 0 & 0.0 & - \\
Slightly ineffective & 53 & 34.9 & - \\
Moderately effective & 39 & 25.7 & - \\
Slightly effective & 27 & 17.8 & - \\
Very effective & 33 & 21.7 & - \\
\hline Total & $\mathbf{1 5 2}$ & $\mathbf{1 0 0 . 0}$ & $\mathbf{3 8}$ \\
\hline
\end{tabular}

SME, small and medium-sized enterprise.

The findings also indicate that $50.7 \%$ of the population's monthly sales are on credit.

\section{Small and medium-sized enterprises use of a credit policy}

The vast majority of the respondents (59\%) do not make use of a credit policy at all. In addition, when respondents were asked to identify the type of credit policy they use when granting trade credit, the findings indicate that $37.5 \%$ of all SMEs in this study do not make use of any particular credit policy when granting trade credit to a customer. The effectiveness of SMEs own credit policies, as perceived by the SME itself, was also tested. The results are tabulated within Table 2 .

Table 2 illustrates the extent to which the SMEs perceive their current credit policy to be effective.

The findings illustrate that the vast majority of the total population perceives its credit policy to be slightly ineffective; therefore, SMEs are not fully able to eliminate the possibility of receiving late payments from debtors, ultimately eliminating bad debts.

\section{The reality of late payments within small and medium-sized enterprises by examination of small and medium-sized enterprises' bad debt relative to sales situation}

Table 3 illustrates the trade credit situation within the SME by focussing on bad debt relative to sales.

The findings indicate that a large percentage of the total population struggle with bad debt and regard a significant percentage of their total sales as bad debt. The last column in Table 3 portrays the actual percentage of bad debts that SMEs write off. This is a definite indication that SMEs mismanage trade credit. Therefore, this issue requires urgent attention.
TABLE 3: Bad debt relative to sales.

\begin{tabular}{lcc}
\hline Bad debt relative to sales & Frequency & Percentage \\
\hline $0 \%-10 \%$ of sales & 67 & 44.1 \\
$11 \%-20 \%$ of sales & 12 & 7.9 \\
$21 \%-30 \%$ of sales & 28 & 18.4 \\
$31 \%-40 \%$ of sales & 29 & 19.1 \\
$51 \%-60 \%$ of sales & 16 & 10.5 \\
\hline Total & $\mathbf{1 5 2}$ & $\mathbf{1 0 0 . 0}$ \\
\hline
\end{tabular}

\section{Comparison of small and medium-sized enterprises' debtor payment situation} pertaining to debtor payment received on due date and not received on due date relative to sales

Table 4 presents the proportion of the SMEs debtors paying on the due date along with the proportion that do not pay on the due date relative to sales.

As indicated in Table 4, SMEs receive a large percentage of total outstanding debt owed, relative to sales, on the due date, as agreed upon between the SME and the debtor. Accordingly, $72.3 \%$ of SMEs receive payment from debtors on the due date within the sales range of $41 \%-60 \%$. Although a substantial percentage of SMEs indicate that not all sales are settled in full on the due date, accounts are in arrears, thus contributing towards cash-flow constraints and, ultimately, bad debt. Furthermore, SMEs do not receive a substantial percentage of total outstanding debtors, relative to sales, on the due date, as $23.7 \%$ of SMEs indicated not receiving payment from debtors on the due date within the sales range of $21 \%-60 \%$. SMEs thus struggle with late payment from debtors. This is a definite indication that SMEs mismanage trade credit.

\section{The reality of late payments within small and medium-sized enterprises: An illustration of small and medium-sized enterprises regularity of late payments received}

Figure 1 illustrates the late payment situation within the $\mathrm{SME}$, focussing on debtors.

The findings indicate that SMEs struggle with late payment from debtors, as the largest percentage of the total population receives payment from debtors on a date later than that agreed upon between the SME and the debtor. The finding that the largest group of the total population $(74.3 \%)$ indicated that the management of trade credit is a problem in their SMEs supports this. The finding further indicates the practice of trade credit mismanagement within SMEs.

\section{Analysis of small and medium-sized enterprises' trade credit terms granted and average debtor days arranged within credit agreement between small and medium-sized enterprises and debtors}

Table 5 illustrates the different trade credit terms granted by SMEs and the average debtor days as arranged with debtors of the SME. 
TABLE 4: Debtor payments received on the due date and not on the due date relative to sales.

\begin{tabular}{|c|c|c|c|c|}
\hline \multirow[t]{2}{*}{ Debtors to sales category } & \multicolumn{2}{|c|}{ Proportion of debtors paying on the due date relative to sales } & \multicolumn{2}{|c|}{ Proportion of debtor not paying on the due date relative to sales } \\
\hline & Frequency & Percentage & Frequency & Percentage \\
\hline $0 \%-10 \%$ of sales & 1 & 0.7 & 72 & 47.4 \\
\hline $11 \%-20 \%$ of sales & 0 & 0.0 & 44 & 28.9 \\
\hline $21 \%-30 \%$ of sales & 16 & 10.5 & 16 & 10.5 \\
\hline $31 \%-40 \%$ of sales & 25 & 16.4 & 13 & 8.6 \\
\hline $41 \%-50 \%$ of sales & 82 & 53.9 & 2 & 1.3 \\
\hline $51 \%-60 \%$ of sales & 28 & 18.4 & 5 & 3.3 \\
\hline Total & 152 & 100.0 & 152 & 100.0 \\
\hline
\end{tabular}

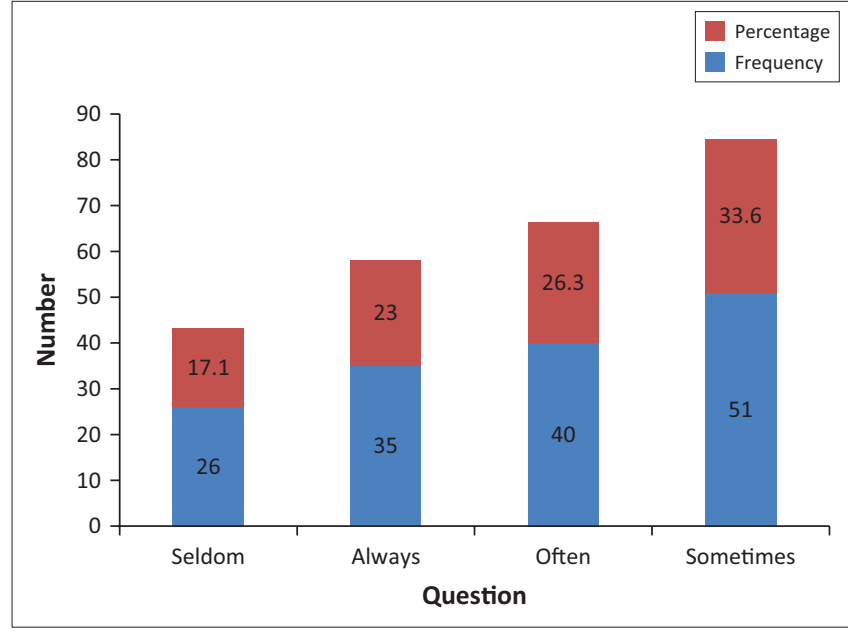

FIGURE 1: Distribution of late payment by debtors.

The findings illustrate that the largest group of the total population grants trade credit on a 30-day basis. However, the largest group of the total population arranges an average debtor days of 55 with their customers to settle the debt owed to them.

\section{Small and medium-sized enterprise-specific constraints with the management of trade credit}

Table 6 illustrates problems that the SME encounter when managing trade credit in terms of cash flow, bad debts, late payments received by debtors or customers and management of debtors.

In terms of Table 6, the findings suggest that the SME encounters problems such as cash flow, bad debts (although to a lesser extent), late payments received by debtors or customers and the management of debtors in managing trade credit. Among the four main problems illustrated in Table 6, the problem of late payments received by debtors or customers (mean equal to 3.92) is the most vital problem to address in effectively managing the SMEs' trade credit management practices, as this mainly constrains SMEs.

\section{Small and medium-sized enterprises' perception pertaining to business failure primarily because of trade credit mismanagement}

Table 7 illustrates the perception towards the management of trade credit for the SME.
TABLE 5: Trade credit terms granted and average debtor days arranged.

\begin{tabular}{lcc}
\hline Variable & Frequency & Percentage \\
\hline Different trade credit terms granted & & \\
$2.5 \%$ within 30 days from statement & 22 & 14.5 \\
$2 / 10$ net 30 days and $5 / 10$ net 60 days $\dagger$ & 29 & 19.1 \\
30 days or net 30 days & 58 & 38.2 \\
60 days net & 38 & 25.0 \\
A $\%$ discount for payment within 30 days & 1 & 0.7 \\
Bank codes and trade references & 3 & 2.0 \\
Company does not give discount. I do grant $1 \%, 1.5 \%$, & 1 & 0.7 \\
$2 \%$ or $2.5 \%$ on 30 days to some customers who pay & & \\
me on 30 days & 152 & 100.0 \\
Total & & \\
Average debtor days as arranged with debtors of the SME & 23 & 15.2 \\
30 days & 48 & 31.6 \\
$30-45$ days & 7 & 4.6 \\
31 days & 10 & 6.6 \\
Local debtors on average 30 days and foreign debtors & & \\
on average 60 days & 1 & 0.7 \\
45 days & 62 & 40.8 \\
55 days & 1 & 0.7 \\
60 days & 152 & 100.0 \\
Total & & \\
\hline
\end{tabular}

SME, small and medium-sized enterprise.

$\dagger$, The $2 / 10$ net 30 days represents a $2 \%$ discount for payment within the 10 -day discount period; the net period ends on day 30 . The $5 / 10$ net 60 days represents a $5 \%$ discount for payment within the 10-day discount period; the net period ends on day 60 .

In terms of Table 7, the findings indicated that the most significant percentage of the total population rates as moderately high the possibility of SMEs failing due to managers' mismanagement of trade credit.

The next section provides a detailed discussion pertaining to the empirical results provided. The section also provides valuable recommendation for SMEs and other stakeholders alike towards effectively managing SME's trade credit management practices.

\section{Discussion}

There are several possible reasons why SMEs find it difficult to manage trade credit effectively and fail to use trade credit successfully as a source of funding.

The vast majority of the respondents extend trade credit to other SMEs and/or customers; therefore, a substantial portion of SMEs' sales is on credit. SMEs are not making use of a credit policy when granting trade credit. The findings indicated that over half of the total population does not make use of a credit policy when granting trade credit. In addition, in terms of the type of credit policy used by SMEs, 37.5\% of the total population does not make use of any particular 
TABLE 6: Main problems encountered with managing trade credit.

\begin{tabular}{|c|c|c|c|c|c|}
\hline Factor & Not a problem or slight problem & Not really a problem & Somewhat of a problem or definite problem & Mean & Ranking \\
\hline Cash flow & 44.7 & 10.5 & 44.7 & 3.42 & 2 \\
\hline Bad debts & 25.0 & 13.8 & 61.2 & 3.18 & 4 \\
\hline $\begin{array}{l}\text { Late payments received by } \\
\text { debtors or customers }\end{array}$ & 20.4 & 1.3 & 78.2 & 3.92 & 1 \\
\hline Management of debtors & 34.2 & 11.8 & 53.9 & 3.21 & 3 \\
\hline
\end{tabular}

TABLE 7: Perception of trade credit mismanagement as the cause for small and medium-sized enterprise failure.

\begin{tabular}{lccc}
\hline $\begin{array}{l}\text { How would you rate the possibility of SMEs } \\
\text { failing, because of mismanagement of trade } \\
\text { credit by managers within the SME? }\end{array}$ & Frequency & Percentage & Mean \\
\hline Extremely high & 16 & 10.5 & - \\
Very high & 38 & 25 & - \\
Moderately high & 79 & 52 & - \\
Do not know & 13 & 8.6 & - \\
Moderately low & 6 & 3.9 & - \\
Very low & 0 & 0 & - \\
Extremely low & 0 & 0 & - \\
\hline Total & $\mathbf{1 5 2}$ & $\mathbf{1 0 0}$ & $\mathbf{2 . 7}$ \\
\hline
\end{tabular}

SME, small and medium-sized enterprise.

credit policy and rather resort to methods such as statements, invoices and telephone calls. To a large extent, SMEs perceive their current credit policies as slightly ineffective. For the largest percentage of the total population, the management of trade credit is a problem in their SMEs. A large percentage of SMEs struggle with bad debt and regard a significant percentage of their total sales as bad debt.

In terms of the portion of debtors paying on the due date, relative to sales, the findings indicated that, for a substantial percentage of SMEs, not all sales are settled in full on the due date. Therefore, the results suggest that SMEs struggle with late payment from debtors. This confirms the findings by Wilson and Summers (2002). Furthermore, the largest percentage of the total population receives payment from debtors on a date later than that agreed upon between the SME and the debtor. The latter is always the case for $23 \%$ of all SMEs.

In terms of providing an identification of the different credit policy terms granted by SMEs, the results indicated that the largest group of the population grants trade credit on a 30day or net 30-day basis. However, the largest group of the population arranges an average debtor day of 55 days with their customers to settle the debt owed to them. This indicates that SMEs aim for a 30-day repayment basis (as set out within many of SMEs' credit policies), but they ultimately arrange a 55-day debtor day average. This finding indicates the strain placed upon cash-flow demands faced by SMEs, which further emphasises the SMEs' difficulties in managing trade credit, as mentioned by Peel et al. (2000) and Peavler (2012). In addition, the findings indicated that, for the largest group of the total population, receiving late payment from debtors is the main problem when managing trade credit. Cash flow, bad debts and the management of debtors are definite problems to SMEs when managing trade credit. Finally, the largest percentage of the total population indicated that there is a moderately high possibility of SMEs failing, as a result of trade credit mismanagement.
The use of a sound and structured credit policy is essential in minimising the effect of late payments from debtors and, therefore, recommended. As stated earlier, the results indicated that over half of the total population does not make use of a credit policy. According to the literature, a credit policy must consist of essential components such as credit period, cash discount, credit analysis, collection policy, evaluating credit policy, management of debtors and age analysis of debtors (Marx et al. 2009). The largest group of the participating SMEs again do not make use of any particular credit policy. Disturbingly, the results indicated that none of the above essential components formed part of the credit policy for SMEs that did make use of a credit policy. All vital credit policy components must form part of the SMEs' credit policy before providing customers with the relevant policy. These credit policy components must enforce a reduction in the amount of outstanding invoices still owed to the SME as well as a reduction in bad debt expenses for the SME. SMEs should begin to adopt a more rigid credit policy approach. As a result of the large number of active debtor accounts among SMEs, indicating that a large number of SMEs sell on credit, and SMEs perceiving their own credit policies as slightly ineffective, it is recommended that SMEs tighten up their credit policies, especially with regard to the credit components within the credit policy, as mentioned by Peavler (2012).

It is also recommended that the government put certain measures and regulations in place to control the bad debt situation within the SME sector. Therefore, measures and regulations need to be put in place to control and prevent late payments made by debtors of the SME. Lastly, training and better communication can also help SME owners understand the concepts of effectively managing trade credit. Therefore, it is suggested that SME owners attend seminars based on practical trade credit- and working capital-management techniques in enabling them to apply these practices to their own enterprise success. This will, in turn, provide SME owners with the necessary managerial competencies, skills and abilities to effectively manage their SME's trade credit practices.

The study sets out to identify the trade credit management situation within the SME environment and, in doing so, establishes whether South African SMEs mismanage trade credit. The next section provides concluding remarks.

\section{Conclusion}

Economic development challenges are common among developing countries. The three main development challenges in a developing country such as South Africa are unemployment, income inequality and poverty. The 
sustainable creation and the survival of SMEs, in particular, hold the key to solving these development challenges for South Africa. The failure rate of SMEs in South Africa is very high. A number of challenges cause the high failure rates of SMEs in South Africa. One of these is the SMEs' mismanagement of trade credit. This article aimed to identify the SMEs' trade credit management practices in the Free State province of South Africa, in order to establish whether SMEs find it difficult and, therefore, struggle to manage trade credit effectively and fail to use trade credit successfully as a source of funding, by examining these specific practices of SMEs. SMEs have a major role to play in the South African economy. They are a vital source of poverty alleviation, reduction of income inequality and economic growth. Furthermore, the creation and development of SMEs contributes positively towards employment and improved living standards and helps diversify economic activity. The mismanagement of trade credit is a key obstacle to their survival and growth and must be addressed forthwith. Therefore, the application of effective trade credit management practices is needed in order to develop SMEs into viable and sustainable businesses.

\section{Limitations and areas for future study}

A dynamic survey to examine the impact of the business environment (internal and external environment) on the management and availability of trade credit as perceived by SMEs could help confirm and expand the findings of this study. The study should be expanded to other provinces in an attempt to provide a more holistic picture of SMEs trade credit management practices on a national level. In addition, a more rigorous statistical analysis, such as inferential statistics, should be employed to further understand SMEs trade credit management practices.

\section{Acknowledgements Competing interests}

The author declares that he has no financial or personal relationships which may have inappropriately influenced him in writing this article.

\section{References}

Balkenhol, B. \& Evans-Klock, C., 2002, Private equity and capitalization of SMEs in South Africa, viewed 02 April 2012, from http://www.ilo.org/public/english/ employment/finance/download/wp.34.pdf

Barad, M.M., 2010, 'A study on liquidity management of Indian steel industry', PhD thesis, Saurashtra University, Rajkot, viewed 25 June 2012, from http://etheses. saurashtrauniversity.edu/id/eprint/77

Beck, T., Demirguc-Kunt, A. \& Peria, M.S.M., 2008, Bank financing for SMEs around the world: Drivers, business models and lending practices, viewed 28 May 2012, from http://ideas.repec.org/p/wbk/wbrswps/4785.html
Berger, A. \& Udell, G., 2006, 'A more conceptual framework for SME financing', Journal of Banking and Finance 30(11), 2945-2966. https://doi.org/10.1016/j. of Banking and

Fatoki, O.O., 2010, 'The impact of the South African business environment on the availability of debt finance to new small and medium enterprises in South Africa', $\mathrm{PhD}$ thesis (Business Management), University of the Free State, Bloemfontein.

Fatoki, O.O. \& Smit, A.V.A., 2010, 'The impact of the business environment on the availability of trade credit to new SMEs in South Africa', African Journal of Business Management 4(9), 1790-1799.

Fazzari, S.M. \& Petersen, B.C., 1993, 'Working capital and fixed investment: New evidence on financing constraints', The Rand Journal of Economics 24(3), 328342. https://doi.org/10.2307/2555961

Finmark Trust, 2006, Fin scope small business survey report, viewed 29 March 2012, from http://www.finmarktrust.org.za

García-Teruel, P.J. \& Martínez-Solano, P.M., 2007, 'Short-term debt in Spanish SMEs', International Small Business Journal 25(6), 579-602. https://doi.org/10.1177/02 66242607082523

García-Teruel, P.J. \& Martínez-Solano, P.M., 2010, 'Determinants of trade credit: A comparative study of European SMEs', International Small Business Journal 28(3), 215-233. https://doi.org/10.1177/0266242609360603

Herrington, M., Kew, J. \& Kew, P., 2009, Global entrepreneurship monitor, South African report, viewed 05 April 2012, from http://www.gbs.net.ac.za/gbswebb/ userfiles/gemsouthafrica2000pdf

Kauffman Foundation, 2007, The capital structure decisions of new firms, viewed 20 September 2012, from http://www.kaufman.org

Main, S.L. \& Smith, C.W., 1992, 'Account receivable management policy: Theory and evidence', The Journal of Finance 47(1), 169-200. https://doi. org/10.1111/j.1540-6261.1992.tb03982.x

Marx, J., De Swardt, C.J., Beaumont-Smith, M. \& Erasmus, P., 2009, Financial management in Southern Africa, 3rd edn., Pearson Education South Africa, Cape Town.

Mass, G. \& Herrington, M., 2006, Global Entrepreneurship Monitor South Africa report, viewed 05 April 2012, from http://www.gemconsortium.org/document. aspx?id756

Ng, C.K., Smith, J.K. \& Smith, R.L., 1999, 'Evidence on the determinants of credit terms used in interfirm trade', Journal of Finance 54(3), 1109-1129. https://doi. org/10.1111/0022-1082.00138

Padachi, K., 2006, 'Trends in working capital management and its impact on firms' performance: An analysis of Mauritian small manufacturing firms', International Review of Business Research Papers 2(2), 45-58.

Peavler, R., 2012, Factors to consider when developing a credit policy, viewed 16 August 2012, from http://bizfinance.about.com

Peel, M.J. \& Wilson, N., 1996, 'Working capital and financial management practices in the small firm sector', International Small Business Journal 14(2), 52-68. https:// doi.org/10.1177/0266242696142004

Peel, M.J., Wilson, N. \& Horworth, C., 2000, 'Late payment and credit management in the small firm sector: Some empirical evidence', International Small Business Journal 18(2), 17-37. https://doi.org/10.1177/0266242600182001

Petersen, M.A. \& Rajan, R.G., 1997, 'Trade credit: Theories and evidence', Review of Financial Studies 10(4), 661-691. https://doi.org/10.1093/rfs/10.3.661

Poutziouris, P., Michaelas, N. \& Soufani, K., 2005, Short-term financial management of working capital in small-medium sized enterprises, viewed 25 November 2013, from https://www.coursehero.com/file/7562732/mfc-130/

Selima, Y.P., 2007, 'Theories of trade credit', Journal of Institute Credit Management $7(2), 16-31$

Sunday, K.J., 2011, 'Effective working capital management in small and medium scale enterprises (SMEs)', International Journal of Business and Management 6(9), 271-279.

Tagoe, N., Nyarko, E. \& Smurfit, M., 2005, 'Financial challenges facing urban SMEs under financial sector liberalization in Ghana', Journal of Small Business Management 43(3), 331-343. https://doi.org/10.1111/j.1540-627X.2005.00140.x

Von Broembsen, M., Wood, E. \& Herrington, M., 2005, Global Entrepreneurship Monitor South Africa report, viewed 25 April 2012, from http://www.gsb.uct. ac.za/gsbwebb/userfiles/gem2005.pdf

Whited, T.M., 1992, 'Debt, liquidity constraints, and corporate investment: Evidence from panel data', The Journal of Finance 47(4), 1425-1460. https://doi. from panel data', The Journal of Fin

Wilson, N. \& Summers, B., 2002, 'Trade credit terms offered by small firms: Survey evidence and empirical analysis', Journal of Business Finance and Accounting 29(3 \& 4), 317-351. https://doi.org/10.1111/1468-5957.00434

World Bank, 2008, South African country brief, viewed 27 August 2013, from http:// siteresource.worldbank.org/GILDSOUTHAFRICA/insolvency\%20law

Zainudin, N. \& Regupathi, A., 2011, 'Manufacturing SMEs credit collection period and its determinants: Some evidence from Malaysia', Folia Oeconomica Stetinensia 9(1), 88-104. 